\title{
Disciplinating the Past The Antiquarian Striving for Interpretative Supremacy
}

\section{Mats Burström}

\begin{abstract}
The establishment of archaeology as a separate discipline involved a disciplination of interpretation. The interpretative task was from now on supposed to be performed solely by professionals. This meant that the former antiquarian interest in ideas held by common people about ancient artefacts and monuments almost vanished in Sweden during the late nineteenth century. Today, with the archaeological focus on the interpretation of meaning, there is a renewed interest in the folklore surrounding ancient objects.
\end{abstract}

Mats Burström, Department of Archaeology, Stockholm University; SE-10691 Stockholm, Sweden.

Before the establishment of archaeology as a separate discipline antiquarians made no distinction, in their interest, between archaeology and folklore. This is evident from the instructions for the first nationwide inventory of ancient monuments ( $\mathrm{Sw}$. Rannsakningar efter antikviteter) that took place in Sweden during the second half of the seventeenth century. In the instructions it is explicitly stated that those carrying out the inventory not only should record the monuments but also carefully inquire about their names and the traditions and stories told about them (cf. Ståhle 1960:xii-xxii).

During the seventeenth and eighteenth centuries the antiquarian interest focused on monuments that were well visible in the landscape. Naturally, these monuments also had attracted the attention of people living in their vicinity and consequently a lot of stories were told about them. This folklore was recorded by the antiquarians. For example, many large mounds were supposed to be built over an- cient kings. Some of them were just called "royal mounds" (Sw. kungshögar) while others were given more specific names such as Ottar's Mound, fig. 1.

The antiquarian interest in folklore continued well into the nineteenth century. This is evident from the antiquarian travel reports initiated and financed by the Royal Academy of Letters, History and Antiquities (Sw. Kungl. Vitterhets Historie och Antikvitets Akademien). They contain an abundance of traditions and stories collected from local people. All this radically changed, however, with the establishment of archaeology as a separate discipline and a modern science.

\section{THE DISCIPLINATION OF ARCHAEOLOGY}

In Sweden the disciplination of archaeology took place during the $1870 \mathrm{~s}$. From then on there were archaeologists with academic titles, annual archaeological meetings, and an extensive publication of archaeological lite- 


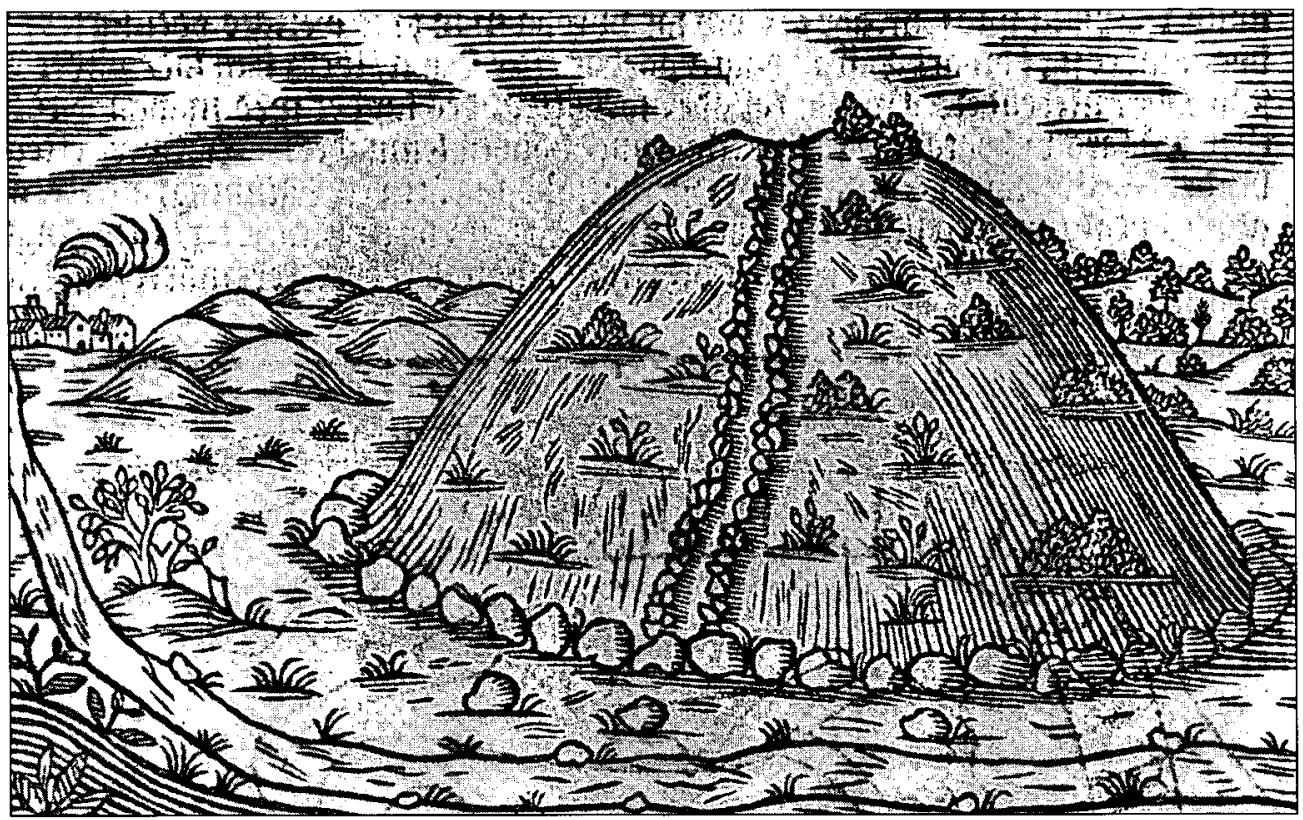

Fig. 1. Ottar's Mound in the province of Uppland, Sweden, depicted by Johan Peringskiöld (1654-1720) in the early eighteenth century (after Lindqvist 1936:43). Locals consider Ottar to have been an ancient king, and they are documented as having used the name of the mound since 1675. Antiquarians and archaeologists have later tried to identify Ottar as a king mentioned by Snorri in the Ynglinga Saga (cf. Lindqvist 1936:39-47).

rature including journals (cf. Welinder 1994: 197-203).

The establishment of archaeology as a modern science in Scandinavia was closely connected with the introduction of the typological method and the construction of large-scale chronological schemes (cf. Gräslund 1987). The early archaeologists considered the creation of a reliable chronological division of the archaeological sources to be the most important task. They felt that if chronological order was not brought into the chaotic sources, it would not be possible to draw correct historical conclusions.

To understand why Swedish archaeology developed the way it did during the 1870 s, it is necessary to consider both the internal archaeological logic and the contemporary context in general. The internal factors have often been emphasized and are comparatively well known (see e.g. Klindt-Jensen 1975; Gräslund 1987; Trigger 1989:73-86). In short the chronological research is seen as a continuation and refinement of the work started with the Dane C. J. Thomsen's (1788-1865) Three-Age System in the 1820-30s. Of importance is also the rapidly growing collections of artefacts at the Museum of National Antiquities (Sw. Statens Historiska Museum) in Stockholm, which made it possible to construct finer and finer chronological schemes.

What has not attracted much attention, is that the archaeological preoccupation with dating coincided with a general busyness in contemporary society with regard to the hand- 
ling and uniformation of time.

\section{FOCUSING ON TIME}

The 1870s was a period of exceptional economical and industrial expansion in Sweden (Lundmark 1989:54). During this development a lot of interest was focused on time as a phenomenon and people's attitude towards it. The new means of communication, telegraphy and railways, demanded an uniform time throughout the nation. This was made clear especially by the problems of handling railway timetables with different regional times. Therefore a nationwide standard time was introduced in Sweden in 1879. As a matter of fact, this is supposed to have been the first official, national, standard time ever to have been introduced (Lundmark 1989:56).

The building of railways was also an important reason for the rapidly growing collections of archaeological artefacts. Considering this and the decisive role of the railway in the introduction of a national standard time, it seems suitable that the development of the railway carriage was used to illustrate the typological series, fig. 2 .

Time was central also for other reasons. The industrial mass-production demanded a new kind of time-disciplination, which had not been necessary in the previous agrarian society. The industrial workers' adjustment to an abstract clock-time was problematic and led to different measures from the authorities (Löfgren 1987). An important external sign of the new attitude towards time was the personal pocket watch, which during the 1870 s more and more became every man's property (Medelius 1989:77). Supervisors who watched over the workers wore a pocket watch with the chain displayed over their chest (Löfgren 1987:31). Oscar Montelius, who as the most

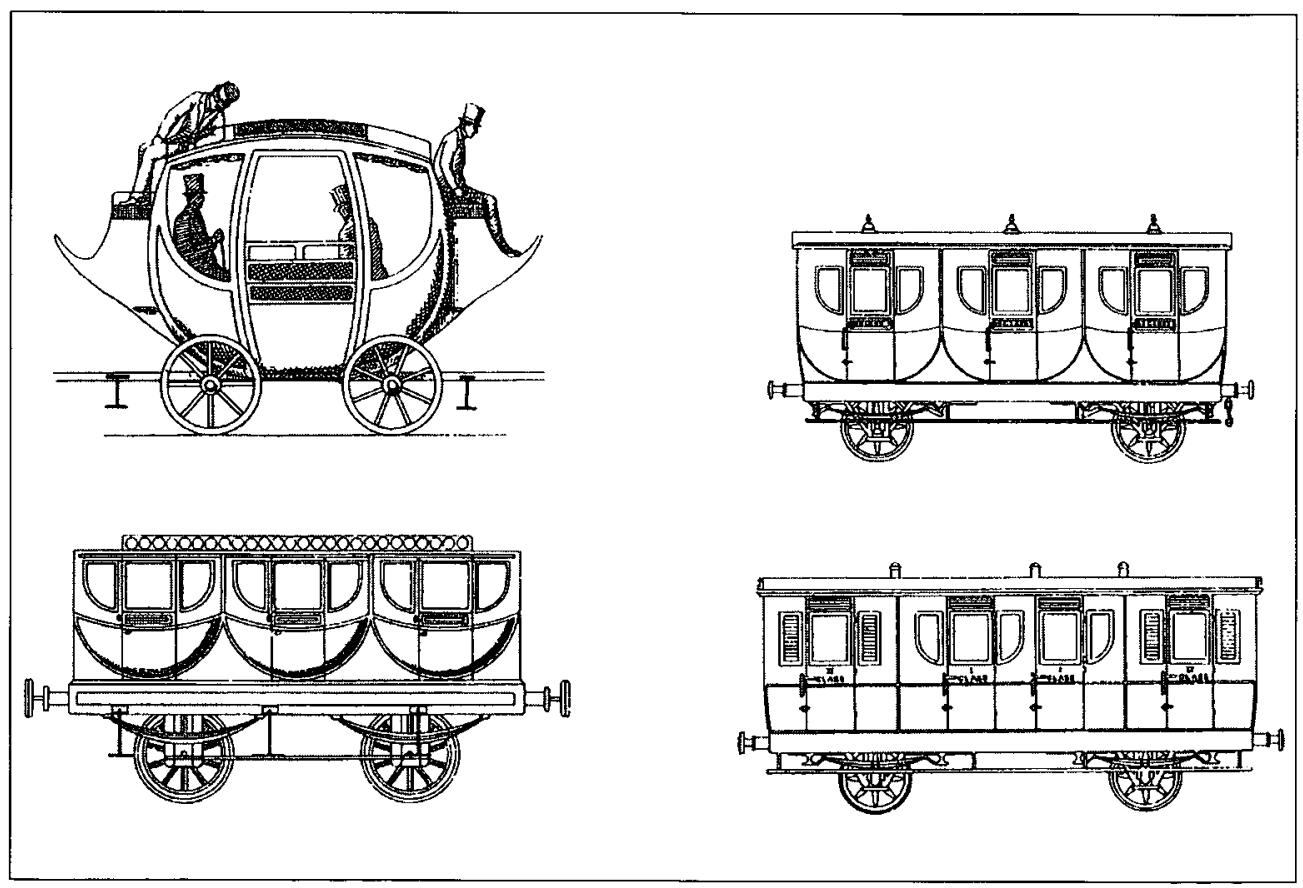

Fig. 2. The typological series - the archaeological method for creating chronological order -illustrated by the development of the railway carriage (after Montelius 1899:262-263). 
famous of the Swedish chronology-constructors successfully tried to control past time, was also portrayed with a well-visible pocket watch-chain, fig. 3 .

It would seem that time was used in Sweden during the late nineteenth century as a means of disciplination in society in general as well as in archaeology. In society, time was used to discipline the Swede to become a useful citizen in an increasingly organized and centralized society (Broberg 1991:889). In archaeology the controlling of time by creating chronological order was an essential part of the establishment of archaeology as a modern science.

\section{DISREGARDING FOLKLORE}

In folklore there was little concern with the dating of ancient monuments. Instead it was the monument's location in the landscape and its appearance that attracted attention. With the more solid chronological frame-

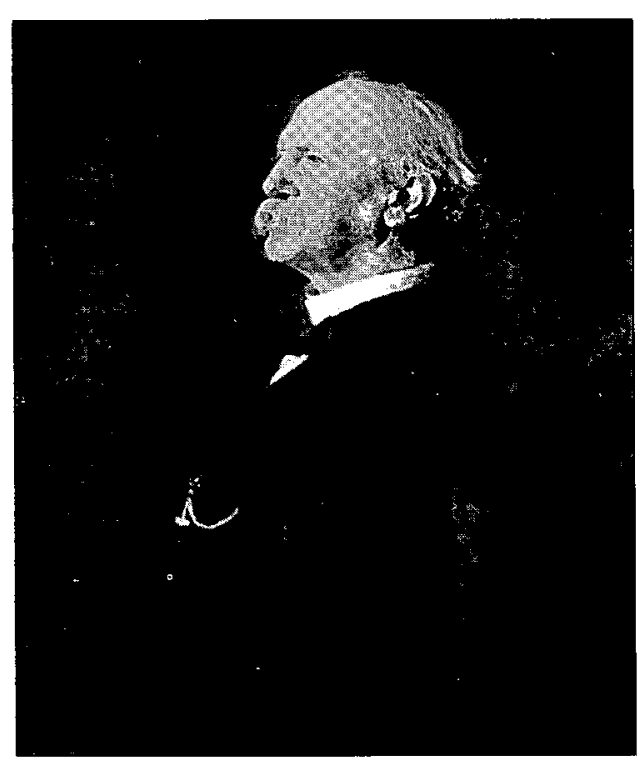

Fig. 3. Oscar Montelius (1843-1921) at the time of his retirement from the Central Board of National Antiquities ( $S w$. Riksantikvarieämbetet). As in earlier portraits (cf. Rydh 1937) the pocket watchchain is well displayed. Painting by Emerik Stenberg in 1913. Photo: ATA. works of the late nineteenth century, the scholarly status and ambition of archaeology grew considerably. The focus on chronological problems and the use of the typological method made archaeological interest center on artefacts, while the interest in ancient monuments diminished (cf. Selinge 1978:76). The interest in the latter was often restricted to the artefacts they might contain. This increased the distance between archaeologists and people in general. While the monuments and the stories told about them continued to attract common man's interest, archaeologists focused on the dating of artefacts and considered the stories told about monuments to be superstition without scientific value.

The antiquarian loss of interest in folklore is, for example, evident from a regional survey of ancient monuments that started in western Sweden during the 1870 s. This survey, known as the "Gothenburg Survey" (Sw. Göteborgsinventeringen) continued with some breaks for half a century (cf. Bertilsson \& Winberg 1978). The survey differed from its predecessors by a sharp restriction to the recording of prehistoric monuments. The survey has been described as "extremely successful" since it ignored "churches, folklore, the recording of local dialects, and much more that previously had encumbered the antiquarian work and reduced its value" (Sarauw \& Alin 1923:16, my translation). This appreciation is an evident illustration of how the disciplination of archaeology altered the antiquarian work. Antiquarians continued to have contact with local people concerning the presence and location of ancient monuments, but they were no longer interested in the stories locals could tell about them. From now on antiquarians were collecting "archaeological "data", and this was not to be confused with unlearned speculation. Hereby the antiquarians founded an interpretative supremacy concerning the understanding of ancient monuments. By virtue of this supremacy, locals were no longer considered as partners in a dialogue but reduced to informants and potential objects for 
adult education. This attitude created a cleavage between the antiquarian authorities and the general public, which still exists.

Today this cleavage concerns, among other things, what kinds of objects are to be considered and protected as ancient monuments. Stone Age settlement sites - often unknown to locals and invisible to the naked eye - are protected while cottage foundations from later centuries, which attract a lot of local interest, are not. However scientifically well-founded this may be, most locals find it hard to understand. They view it as an antiquarian ignorance of the local and nonprofessional interest.

\section{FOCUSING ON MEANING}

During recent years archaeology has focused interest on the interpretation of meaning. It has been acknowledged that the meaning of ancient monuments is not restricted to the time when they came into being. On the contrary, they have repeatedly attracted attention and been ascribed meaning throughout history (cf. e.g. Bradley 1993; Burström 1989, 1993, 1996a, 1996b; Chippindale 1983;

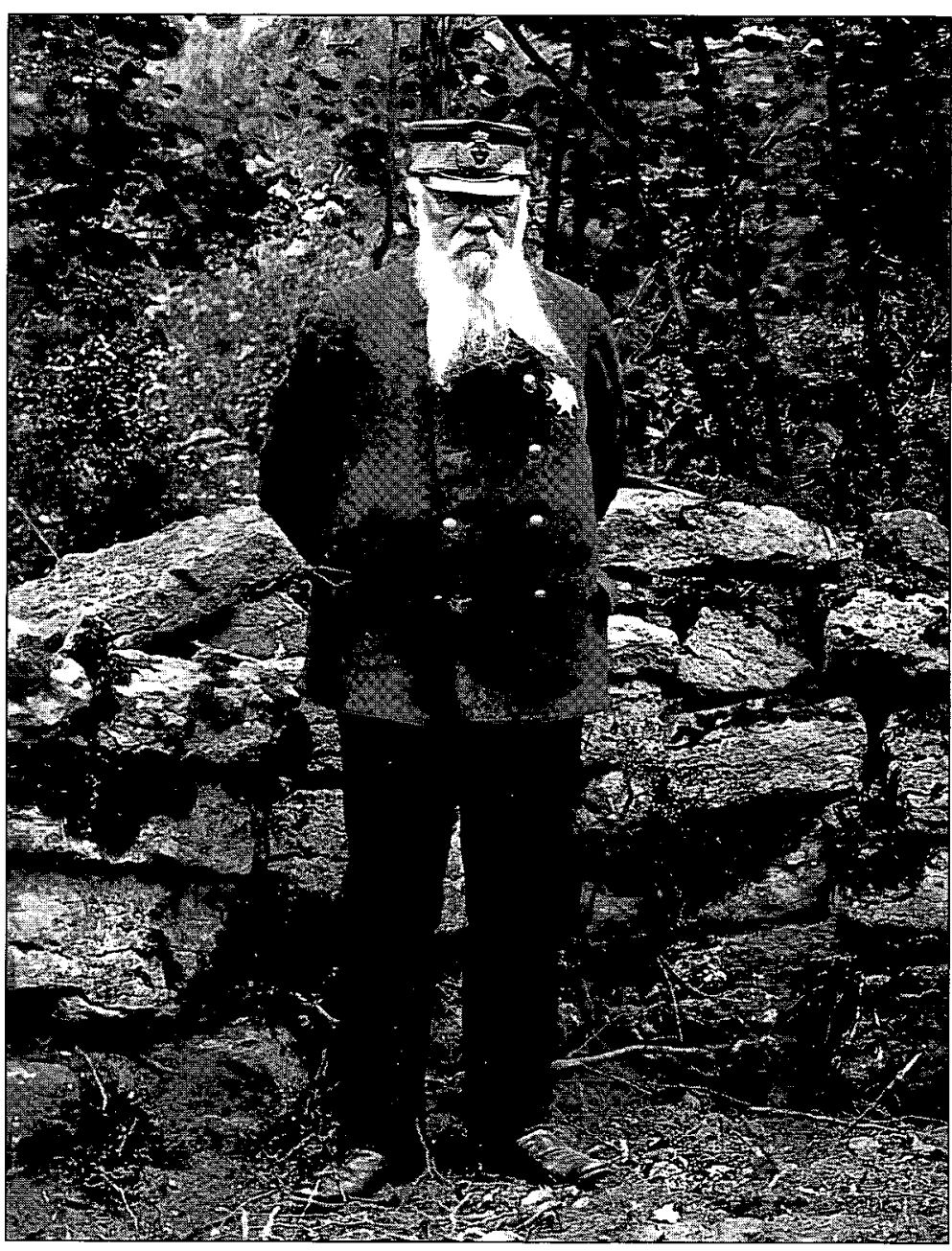

Fig. 4. The directorgeneral of the Central Board of National Antiquities (Sw. Riksantikvarien) Hans Hildebrand (1842-1913) in his official uniform adorned with the Swedish grand cross, inspecting excavation work in 1904. The uniform stresses the slpreme antiquarian position.

Photo: ATA 
Holtorf forthcoming; Strömberg 1995).

Ancient monuments are no longer looked at as just carriers of information about prehistory, they are also considered to have a cultural value (Burström 1993:7). This is constituted of the multitude of meanings that we and earlier generations have ascribed to the monuments. An essential part of the monuments' cultural value is formed by the folklore surrounding them. The archaeological focus on meaning has thus created a renewed interest in folklore.

The interest in different kinds of meaning is a good base for the antiquarian authorities to reconsider their interpretative supremacy and start a dialogue with the general public. Such a dialogue once existed but was broken when archaeology was established as a separate discipline and a modern science. Now, after more then a century of well-disciplined archaeology, I believe it is high time to re- open that dialogue. It will not only help to create a better understanding of why ancient monuments are worth preserving, it will also enhance the monuments' cultural value.

\section{English revised by Laura Wrang.}

\section{ACKNOWLEDGEMENTS}

This text was originally presented at the "Folklore and Archaeology" session at the TAG Conference in Liverpool in December 1996. I want to thank Cornelius Holtorf for inviting me to this session and Torun Zachrisson for our joint work with the book Fornlämningar och Folkminnen from which parts of the present discussion originate.

\section{ABBREVIATION}

ATA Antikvarisk Topografiska Arkivet, Stockholm. (The Antiquarian Topographical Archive, Stockholm.)

\section{REFERENCES}

Bertilsson, U. \& Winberg, B. 1978. Bohuslän - ett experimentområde. Fomvännen. Stockholm. Pp. 97-107.

Bradley, R. 1993. Altering the Earth. The Origins of Monuments in Britain and Continental Europe. The Rhind Lectures 1991-92. Society of Antiquaries of Scotland, Monograph Series Number 8. Edinburgh.

Broberg, G. 1991. Hur mycket är klockan? In: Gyllene Äpplen. Svensk idéhistorisk läsebok. Atlantis. Stockholm. Pp. 876-892.

Burström, M. 1989. Kronologi och kontext. Om samtidighetens relevans för den arkeologiska tolkningen. In: Mänsklighet genom millennier. En vänbok till Åke Hyenstrand. Stockholm. Pp. 37-41.

- 1993. Mångtydiga fornlämningar: En studie av innebörder som tillskrivits fastafornlämningar i Österrekarne härad, Södermanland. Stockholm Archaeological Reports, Nr 27.

- 1996a. Other Generations' Interpretations and Use of the Past: the Case of the Picture Stones on Gotland. Current Swedish Archaeology, Vol. 4. Stockholm. Pp. 21-40.

- 1996b. Skalunda hög. Historier kring en hög. In: Mellan bronssköld och JAS-plan - glimtar av Lidköpingsbygdens historia. Lidköping. Pp. 78-92.

Chippindale, C. 1983. Stonehenge Complete. Thames and Hudson. London.

Gräslund, B. 1987. The Birth of Prehistoric Chronology. Dating methods and dating systems in nineteenth-century Scandinavian archaeology. New Studies in Archaeology. Cambridge University Press. Cambridge.

Holtorf, C. J. forthcoming. Towards a Chronology 
of Megaliths. Understanding Monumental Time and Cultural Memory. Journal of European Archaeology, Vol. 4.

Klindt-Jensen, O. 1975. A History of Scandinavian Archaeology. Thames and Hudson. London.

Lindqvist, S. 1936. Uppsala högar och Ottarshögen. Kungl. Vitterhets Historie och Antikvitets Akademien. Stockholm.

Lundmark, L. 1989. Tidens gång och tidens värde. Författarförlaget Fischer \& Rye.

Löfgren, O. 1987. Människan och tiden. In: Frykman, J. \& Löfgren, O. Den kultiverade människan. Skrifter utgivna av Etnologiska sällskapet i Lund 11. Liber. Malmö. Pp. 21-44.

Medelius, H. 1989. Om bondens år och arbetets tid. In: Människan och Tiden. Katalog för utställning på Läckö slott. Västergötlands turistråd. Skövde. Pp. 71-80.

Montelius, O. 1899. Typologien eller utvecklingsläran tillämpad på det menskliga arbetet. Svenska Fornminnesföreningens Tidskrift. Tionde bandet. Pp. 237-268.

Rydh, H. 1937. Oscar Montelius. En vägrödjare genom årtusenden. Åhlén \& Söners Förlag. Stockholm.

Sarauw, G. \& Alin, J. 1923. Götaälvområdets fornminnen. Skrifter utgivna till Göteborgs Stads trehundraårsjubileum genom jubileumsutställningens publikationskommitté III. Göteborg.

Selinge, K-G. 1978. Fornlämningsregistret som forskningsunderlag. Några synpunkter med norrländska exempel. Fornvännen. Stockholm. Pp. 75-90.

Strömberg, M. 1995. Fornminne med många uttolkare. Ales stenar inspirerar fackmän och allmänhet. Ale. Historisk tidskrift för Skäne, Halland och Blekinge, Nr 4, 1995. Pp. 1-15. Lund.

Ståhle, C. I. (Ed) 1960. Rannsakningar efter antikviteter. Band I, häfte I. Kungl. Vitterhets Historie och Antikvitets Akademien. Stockholm.

Trigger, B. G. 1989. A History of Archaeological Thought. Cambridge University Press. Cambridge.

Welinder, Stig. 1994. Strindberg som arkeologikritiker. Almqvist \& Wiksell International. Stockholm. 
